\title{
DC Motor with Hysteresis Band Current Control Technique
}

\author{
Vikramarajan Jambulingam \\ Electrical and Electronics Engineering, VIT University, India
}

\begin{abstract}
In general the high performance motor drive are nothing but a motor drive in which a drive system should have good load regulating response and dynamic speed command tracking. Therefore in acceleration and deceleration the dc motor provides excellent control in speed. In this project the mathematical model for the dc motor with hysteresis band current control technique is designed and tested through the MATLAB/Simulink software.
\end{abstract}

Keywords: Speed control, DC motor, current control technique, separately excited DC motor and Hysteresis band

\section{Introduction}

The variable speed, reliability and high performance are three main characteristics of an electric drive system due to which it can be easily controlled. The field of motor is connected directly to the power supply for the speed control. At the same time it is necessary for torque and speed control. For low horsepower dc drives are low cost. In addition to this for overhauling loads dc regenerative drives are used. By field control method and armature control method wide range of speed control both above and below the rated speeds are achieved. Therefore dc motors are used in fine speed applications such as in paper mills and in rolling mills.

In general on the basis of dc motor excitation the dc motor are classified into two types. They are separately excited and self excited dc motor. In this project we used separately excited dc motor. Hence its field winding and armature are excited from two different sources. The fundamental of electric drives, power electronic circuits, devices and application are explained in detail [1-3].

\section{Construction and Working Principle of DC} Motor

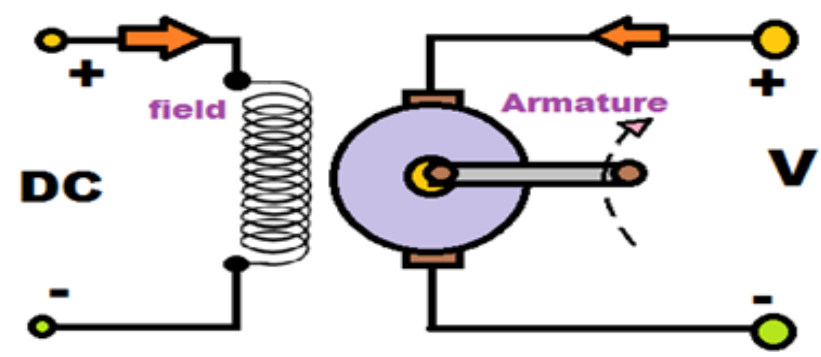

Figure 1: DC motor

The Figure $\{2\}$ shows the proposed hysteresis band current control technique. Singh, Dewangan and Afrasiabi has explained in detail about the chopper control, PWM based automatic closed loop control and DC motor control respectively[6-8].In this proposed method it consist of two loops. They are speed and current loop. In speed loop the saturation conditions takes place. Actually in saturation block it has two limits. The limits are upper limit and lower
In the figure $\{1\}$ with separate supply the separately excited $\mathrm{dc}$ motor has field and armature winding. To excite the field flux the field winding of the dc motor is used. For mechanical work current in armature circuit is supplied to the rotor through brush and commutator.The field flux and armature current interaction produces rotor torque.Okbuka and raju singh has explained about the performance characteristics of controlled separately excited dc motor and stability analysis of separately excited dc motor respectively [4-5]. The working principle of seperately excited dc motor is listed in points below.

Point 1: The field current $\{$ if $\}$ excites the separately excited dc motor.

Point 2: In the circuit armature current $\{$ ia $\}$ flows.

Point 3: To balance load torque at particular speed. The motor develops a back emf and torque.

Point 4: Any change in armature current has no effect on the field current $\{$ if independent of ia $\}$.

Point 5: The field current $\{$ if $\}$ is much less than the armature current $\{$ ia $\}$.

\section{Proposed HB Current Control Technique}

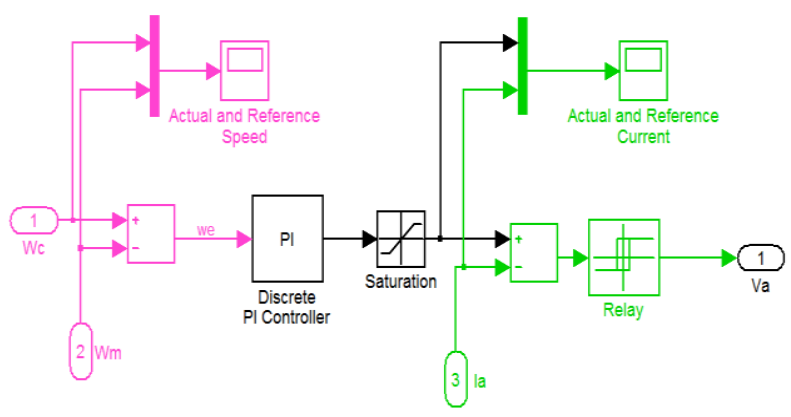

Figure 2: Proposed HB current control technique

limit with value twenty and zero respectively. In current loop the relay setting conditions takes place. Therefore the relay setting conditions are as follows;

Condition 1: Switch on point: 2

Condition 2: Switch off point:-2

Output when on: 60

Output when off: 0 


\section{International Journal of Science and Research (IJSR) \\ ISSN (Online): 2319-7064}

Index Copernicus Value (2013): 6.14 | Impact Factor (2015): 6.391

\section{Mathematical Equations of Separately Excited DC Motor}

Armature equation,

$V_{a}=E_{g}+I_{a} R_{a}+L_{a}\left\{\frac{d I_{a}}{d t}\right\} \rightarrow$ Equation.1

Armature resistance in ohms $\{\mathrm{Ra}\}$

Armature inductance in Henry $\{\mathrm{La}\}$

Armature voltage in volts $\{\mathrm{Va}\}$

Armature current in amps $\{\mathrm{Ia}\}$

Motor back emf in volts $\{\mathrm{Eb}\}$

Torque equation,

$T_{d}=J \frac{d \omega}{d t}+B \omega+T_{L} \rightarrow$ Equation. 2
Load torque in Newton-Meter $\left\{\mathrm{T}_{\mathrm{L}}\right\}$

Friction co-efficient of the motor $\{\mathrm{B}\}$

Moment of inertia in $\mathrm{Kg} / \mathrm{m}^{2}\{\mathrm{~J}\}$

Torque developed in Newton-Meter $\left\{\mathrm{T}_{\mathrm{d}}\right\}$

Angular velocity in $\mathrm{rad} / \mathrm{sec}\{\mathrm{w}\}$

\section{Simulation Model of DC Motor Using HB} Current Control Technique

Armature resistance $\{\mathrm{Ra}\}=2.2 \mathrm{ohms}$

Armature inductance $\{\mathrm{La}\}=5.6 \mathrm{mH}$

Moment of inertia $\{\mathrm{J}\}=1$.e-4

Friction coeffient of the motor $\{\mathrm{F}\}=1 \mathrm{e}-3$

$\mathrm{Kb}=\mathrm{Ki}=0.1$

Rated voltage $\{$ Vrated $\}=60$ volt

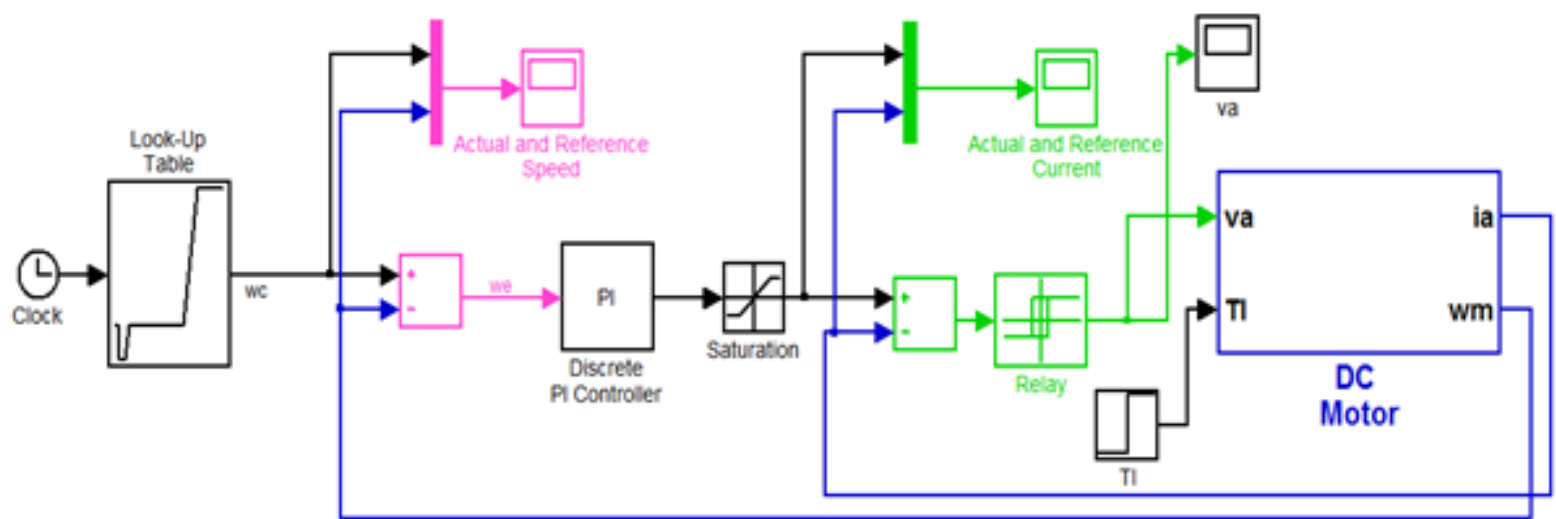

Figure 3: Simulation model of dc motor with HB current control technique

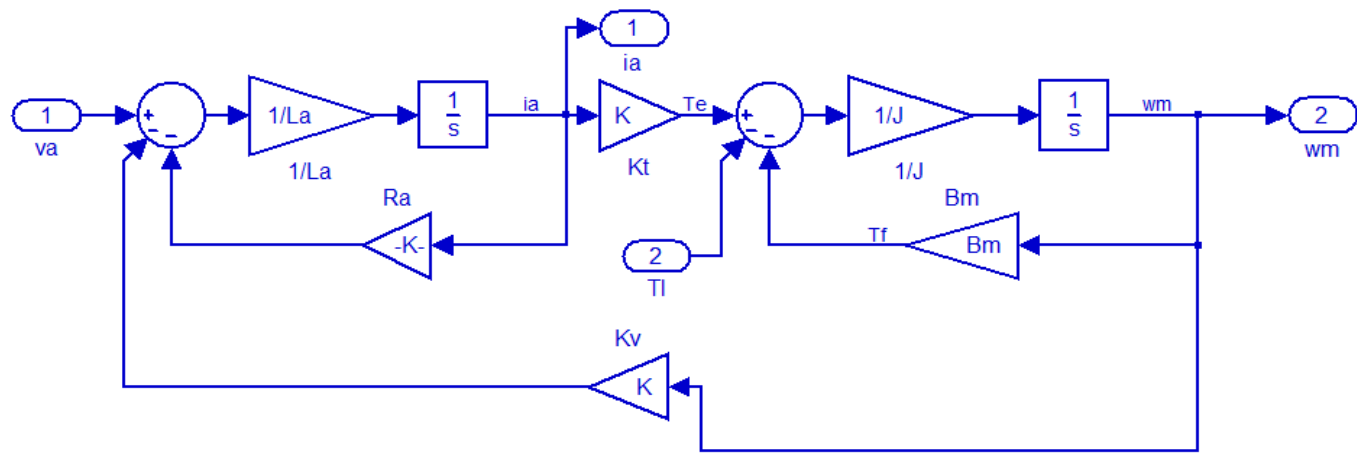

Figure 4: Subsystem simulation model of dc motor

\section{Simulation Results}

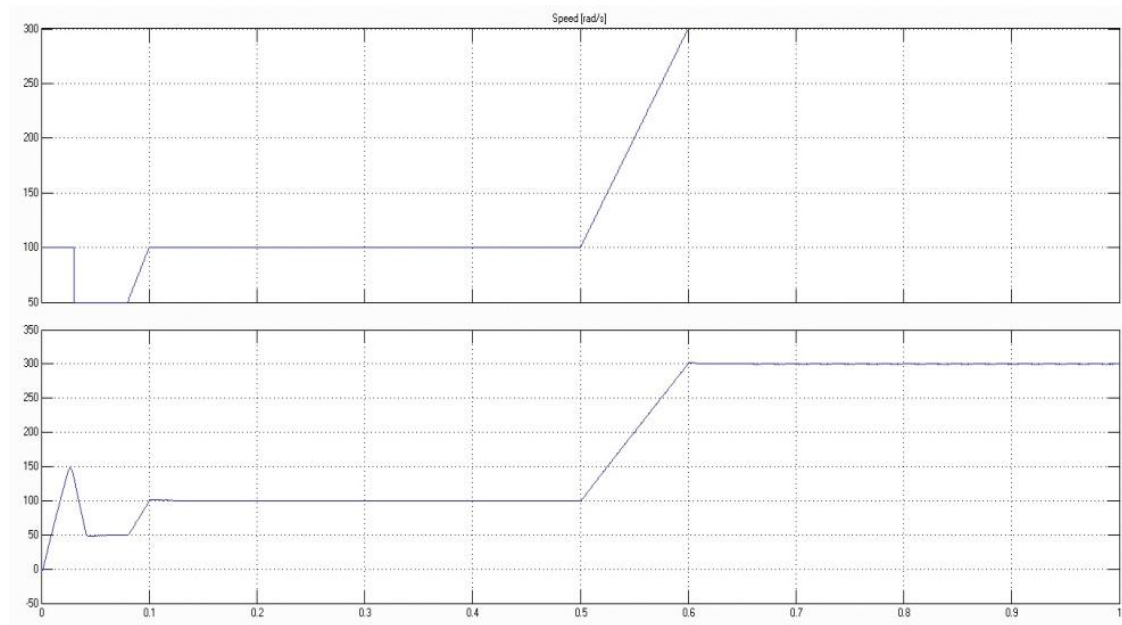

Figure 5: Reference speed and Actual speed

Volume 5 Issue 6, June 2016 www.ijsr.net

Licensed Under Creative Commons Attribution CC BY 


\section{International Journal of Science and Research (IJSR) \\ ISSN (Online): 2319-7064}

Index Copernicus Value (2013): 6.14 | Impact Factor (2015): 6.391
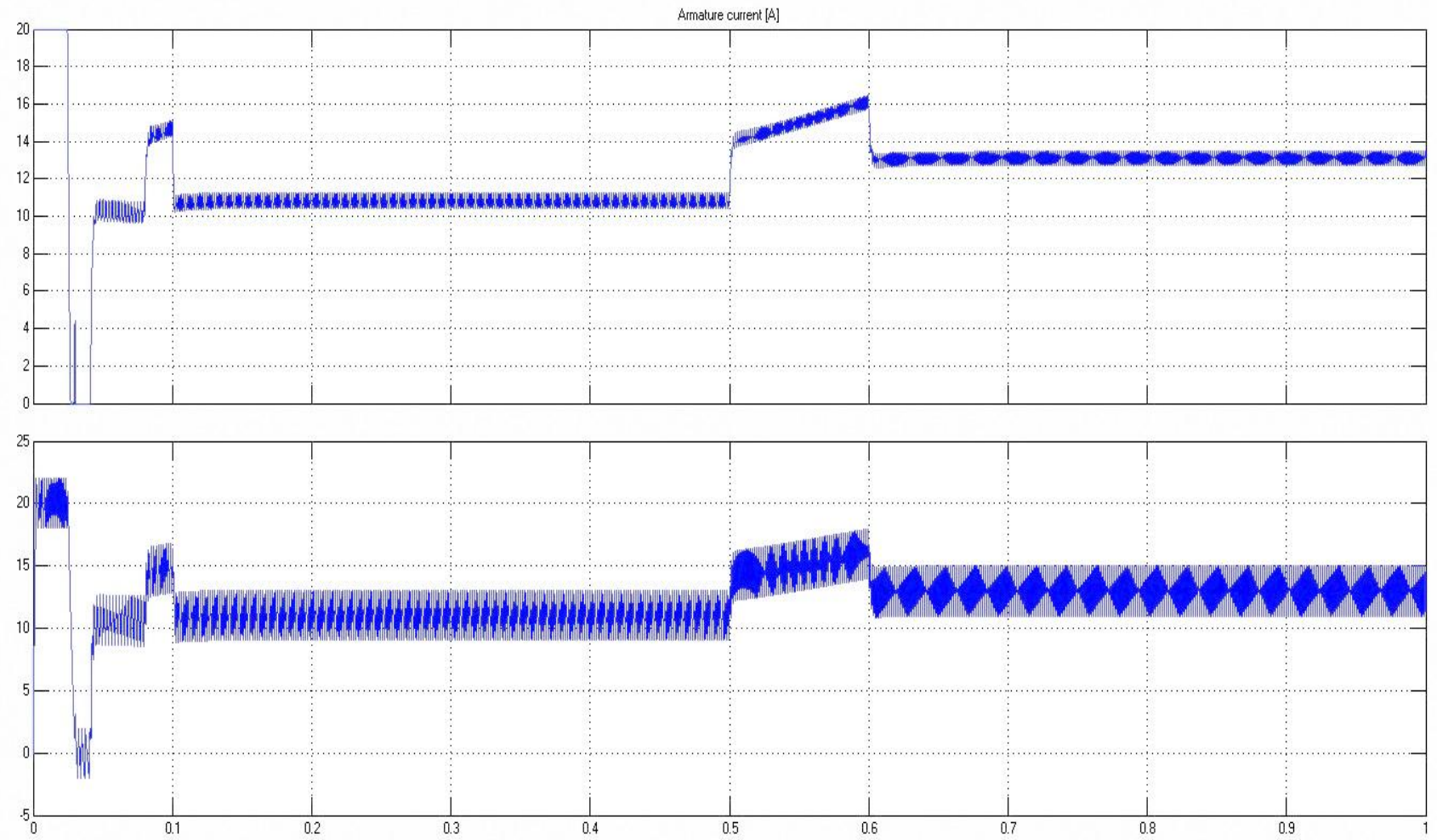

Figure 6: Reference current and Actual current

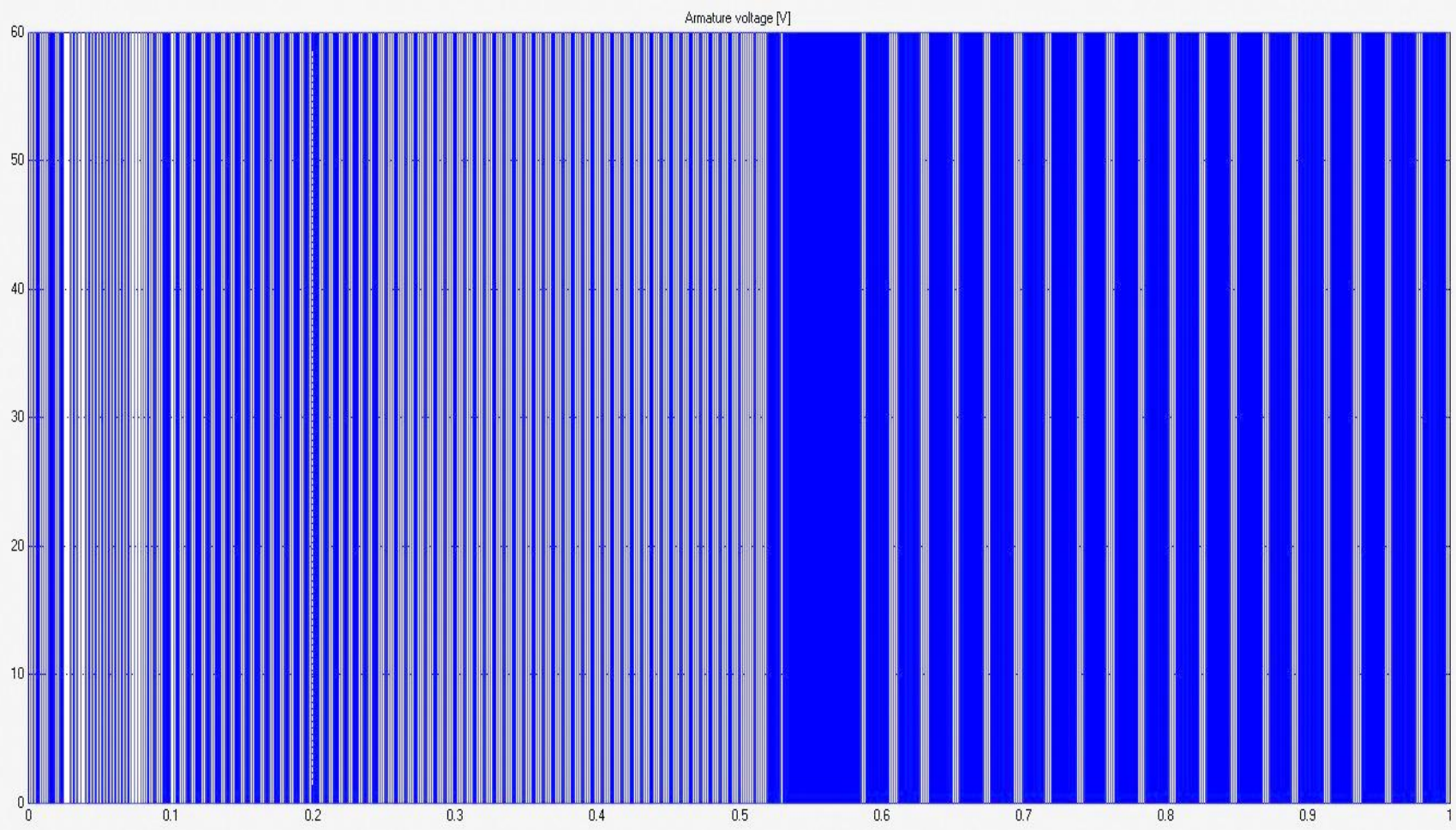

Figure 7: Actual Voltage

\section{Conclusion}

The dc motor is the backbone of industrial applications. The industrial application needs high performance motor drives. The dc motor is used as an adjustable speed machine for this wide range of option is evolved. The four main reasons for the usage of $\mathrm{dc}$ motors are reliability, simplicity and favorable cost. At the same time the dc motor drive is less complex compare to ac motor drives.

\section{References}

[1] Gopal K. Dubey, "Fundamentals of Electric Drives", Narosa Publishing House, New Delhi, 1989.

[2] Muhammad H.Rashid, "Power Electronics Circuits, Devices and Applications", Prentice Hall, 3rd Edition, 2003.

[3] Bimbra P.S, "Power Electronics", Khanna Publishers, New Delhi, 2006. 


\section{International Journal of Science and Research (IJSR) \\ ISSN (Online): 2319-7064}

Index Copernicus Value (2013): 6.14 | Impact Factor (2015): 6.391

[4] C.U.Ogbuka, "Performance Characteristics of Controlled Separately Excited DC Motor", Pacific Journal of Science and Technology, Volume 10, Number 1, May 2009.

[5] Raju Singh, Dr.A.K.Pandey, "Stability Analysis of Separately Excited DC Motor", GJCAT, Vol 2(1), 2012.

[6] S.N.Singh and D.R.Kohli,"Performance Determination of a Chopper Controlled Separately Excited DC Motor", IEEE Transaction on Industrial Electronics, Vol.31, No.1, February 1986.

[7] A.K.Dewangan and N.Chakraborty, "PWM Based Automatic Closed Loop Speed Control of DC Motor", International Journal of Engineering Trends and Technology, Volume 3, Issue 2, 2012.

[8] N.Afrasiabi and M.H.Yazdi, "DC Motor Control Using Chopper", Journal of Science, Engineering and Technology, Issue 8, pp. 67-73, GJSET Publishing, 2013.

\section{Author Profile}

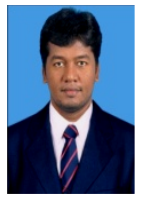

Mr. J. Vikramarajan received his Master degree in Power Electronics and Drives and Bachelor degree in Electrical and Electronics Engineering from VIT University, India. $\mathrm{He}$ has published several international research books and journals. His research interests are electrical machines, power electronic applications, power quality, power electronic converters and power electronic controllers for renewable energy systems.

Volume 5 Issue 6, June 2016 www.ijsr.net 